\title{
PRODUCTIVITY AND CONTENT OF MACRO- AND MICROELEMENTS IN THE PHYTOMASS OF GROUND VEGETATION OF TYPICAL AND UNIQUE TAIGA FORESTS OF THE NORTHERN URALS (EXAMPLE OF SPRUCE-FIR FORESTS OF THE PECHORA-ILYCH NATURE RESERVE)
}

\author{
A. P. Geraskina', O. V. Smirnova', V. N. Korotkov' ${ }^{2}$ I. Yu. Kudrevatykh ${ }^{3}$ \\ ${ }^{1}$ Center for ecology and forest productivity of the Russian Academy of Sciences, 84/32 Profsoyuznaya street, Moscow, 117485, Russia \\ E-mail:angersgma@gmail.com \\ ${ }^{2}$ Institute of global climate and ecology named after academician Yu. A. Israel, 20B Glebovskaya street, Moscow, 107258, Russia \\ E-mail:korotkovv@list.ru
}

${ }^{3}$ Institute of physical, chemical and biological problems of soil science RAS, b. 2, 2 Institutskaya street, Pushchino, Moscow region, 142290, Russia E-mail:angersgma@gmail.com

\begin{abstract}
Most woodlands of the Northern Eurasia are represented by bilberry-green moss spruce-fir forests. At the same time, a tall herb type of spruce-fir forests that occupies a much smaller area was identified and described. The objective of this work is to evaluate and compare the species richness and productivity of the ground vegetation of tall herb spruce-fir (unique) and bilberry-green moss spruce-fir (typical) forests of the Northern Urals. Based on previous studies, two forest types were selected in the foothill part of the Pechora-llych nature reserve with tall herb and bilberry-green moss ground vegetation, where total mapping, determination of microsite area and geobotanical descriptions had been carried out previously. Material for determination of the aboveground and below-ground phytomass and chemical composition of plant species was collected in $2017-2018$. The concentrations of $\mathrm{C}$ and $\mathrm{N}$ in plant samples were measured on the elemental analyzer, and $\mathrm{Mg}, \mathrm{Al}, \mathrm{P}, \mathrm{S}, \mathrm{Cl}, \mathrm{K}$, $\mathrm{Ca}, \mathrm{Fe}$, and $\mathrm{Zn}$ content was found using the method of measuring mass fraction of the element in powder samples by X-ray fluorescence analysis. It was found out that the total phytomass of vascular plants in the ground vegetation of tall herb forests is 5 times higher than that of bilberry-green moss forests. The phytomass of mosses, on the contrary, is 4.4 times lower in tall herb forests in comparison with bilberry-green moss forests. Examination of ecological-coenotic groups of plants in terms of the content of chemical elements taking phytomass in consideration shows that the greatest contribution to the accumulation of macro- and microelements in the tall herb spruce-fir forest is made by the plants from tall herbs, boreal dwarf shrubs and boreal small herbs groups; in the bilberry-green moss spruce-fir forest, the main role is played by mosses and boreal dwarf shrubs. To assess the content of biogenic elements in the ground vegetation a differentiated approach was suggested, which included accounting for above-ground and below-ground phytomass by ecological-coenotic groups of plants within different types of microsites.
\end{abstract}

Keywords: boreal forests, biodiversity, tall herb spruce-fir forests, bilberry-green moss spruce-fir forests, microsites, above-ground phytomass, below-ground phytomass, ecological-coenotic groups of plants, macroelements, microelements, ground vegetation.

Acknowledgments. The research was carried out within the framework of the State Task of the Center for Problems of Ecology and Productivity of Forests, Russian Academy of Sciences AAAA-A18-118052590019-7, with the financial support of the Russian Foundation for Basic Research (19-04-00-609 A).

For citation: Geraskina A.P., Smirnova O.V., Korotkov V.N., Kudrevatykh I.Yu. Productivity and content of macro- and microelements in the phytomass of ground vegetation of typical and unique taiga forests of the Northern Urals (example of spruce-fir forests of the Pechorailych nature reserve). Russian Journal of Ecosystem Ecology. 2020;5(2). Available from: https://doi.org/10.21685/2500-0578-2020-2-1 


\title{
ПРОДУКТИВНОСТЬ И СОДЕРЖАНИЕ МАКРО- И МИКРОЭЛЕМЕНТОВ В ФИТОМАССЕ ЖИВОГО НАПОЧВЕННОГО ПОКРОВА ТИПИЧНЫХ И УНИКАЛЬНЫХ ТАЕЖНЫХ ЛЕСОВ СЕВЕРНОГО УРАЛА (НА ПРИМЕРЕ ПИХТО-ЕЛЬНИКОВ ПЕЧОРО-ИЛЫЧСКОГО ЗАПОВЕАНИКА)
}

\author{
А. П. Гераськина', О. В. Смирнова', В. Н. Коротков ${ }^{2}$, И. Ю. Кудреватых ${ }^{3}$ \\ ${ }^{1}$ Центр по проблемам экологии и продуктивности лесов РАН, 117485, Россия, г. Москва, ул. Профсоюзная, 84/32 \\ E-mail: angersgma@gmail.com
}

${ }^{2}$ Институт глобального климата и экологии имени академика Ю. А. Израэля, Россия, 107258, г. Москва, ул. Глебовская, 20Б E-mail:korotkovv@list.ru

${ }^{3}$ Институт физико-химических и биологических проблем почвоведения РАН,

Россия, 142290, Московская обл., г. Пущино, ул. Институтская, 2, стр. 2

E-mail:angersgma@gmail.com

Аннотация. Большая часть лесных массивов Северной Евразии представлена чернично-зеленомошными пихто-ельниками. В то же время выделен и описан высокотравный тип пихто-ельников, который занимает значительно меньшие площади. Цель данной работы: оценить и сопоставить видовое богатство и продуктивность напочвенного покрова высокотравных пихто-ельников (уникальных) и чернично-зеленомошных пихто-ельников (типичных) Северного Урала. На основе предшествующих исследований были выбраны два типа леса в предгорной части Печоро-Илычского заповедника с высокотравным и чернично-зеленомошным напочвенным покровом, где ранее было проведено сплошное картирование, определение площади микросайтов и геоботанические описания. Сбор материала для определения надземной и подземной фитомассы и химического состава видов напочвенного покрова был проведен в 2017-2018 гг. В образцах растений измеряли концентрацию C, N на элементном анализаторе и содержание $\mathrm{Mg}, \mathrm{Al}, \mathrm{P}, \mathrm{S}, \mathrm{Cl}, \mathrm{K}, \mathrm{Ca}, \mathrm{Fe}$ и Zn по методике измерения массовой доли элемента в порошковых пробах методом рентгено-флуоресцентного анализа. Установлено, что суммарная фитомасса сосудистых растений напочвенного покрова высокотравных лесов в 5 раз выше, чем чернично-зеленомошных. Фитомасса мхов, напротив, в высокотравных лесах в 4.4 раза ниже в сравнении с чернично-зеленомошными. Исследование эколого-ценотических групп растений по содержанию химических элементов с учетом фитомассы показывает, что наибольший вклад в накопление макро- и микроэлементов в высокотравном пихто-ельнике вносят растения, относящиеся к группам высокотравья, бореальных кустарничков и бореального мелкотравья; в чернично-зеленомошном пихто-ельнике - мхи и бореальные кустарнички. Предложен дифференцированный подход для оценки содержания биогенных элементов в напочвенном покрове, включающий учет надземной и подземной фитомассы по экологоценотическим группам растений в пределах микросайтов разных типов.

Ключевые слова: бореальные леса, биоразнообразие, высокотравные пихто-ельники, чернично-зеленомошные пихто-ельники, микросайты, надземная фитомасса, подземная фитомасса, эколого-ценотические группы растений, макроэлементы, микроэлементы, живой напочвенный покров.

Благодарности. Работа выполнена по теме ГЗ цЭПЛ РАН "Методические подходы к оценке структурной организации и функционирования лесных экосистем" номер государственной регистрации АААА-А18-118052590019-7и при финансовой поддержке проекта РФФИ (19-04-00-609 A).

Currently, it is evident that the modern forest cover of the Earth is essential in maintaining the stability of climate and hydrological regime. Therefore, special importance is attached to large woodlands including dark coniferous forests of Northern Eurasia which many authors considered natural formations $[1,2]$. However, generalization of progressively increasing paleodata shows that modern forests of the Northern Eurasia resulted from almost complete destruction by the primitive man of the key species of prehistoric forests in the Pleistocene-Holocene, i.e. giant herbivores of the mammoth complex which determined the species composition, structure, productivity and climate- regulating functions of the biota of this territory [3-6]. This has led to fundamental changes in the structural and functional organization of currently existing forests. In the late Pleistocene and during the Holocene, the remaining fragments of forests degraded in most of the analyzed territory; logging, clearing, burning and other human impacts led to a significant decrease in the species composition and population of trees, further reduction in the number and species diversity of terrestrial vertebrates and invertebrates, degradation of soil biota and catastrophic depletion of soil $[7,8]$.

These significant forest transformations demonstrated the need not only for conservation, but also 
for restoration of forests which is a condition for the implementation of ecosystem functions of the biosphere [9]. In this regard, special attention was drawn to the not yet completely degraded fragments of forests that were preserved in refugia. Studying vegetation and soil cover of taiga forests in nature reserves, reserves and other refugia allowed identifying and describing a unique type of forest communities of Northern Eurasia, i.e. tall herb spruce-fir forests - Piceeto-Abieta magnoherbosa [10] and mapping their current distribution [11].

To date, tall herb spruce-fir forests have been found and described on a vast territory: from the northern limits of the forest belt (Yamal Peninsula) to southern taiga (Middle Urals) [12-14]. Their species diversity and the ability to exist in a harsh climate preserving nevertheless the nemoral-boreal nature of the flora and, in particular, the presence of early spring ephemeroids that currently mark the zone of broad-leaved forests, confirms the significance of research of tall herb forests for the reconstruction of the prehistoric appearance of the Eurasian taiga.

Objective: to evaluate and compare the productivity and content of macro- and microelements in the phytomass of the ground vegetation of tall herb spruce-fir forests (Piceeto-Abieta magnoherbosa) and bilberry-green moss spruce-fir forests (Piceeto-Abieta hylocomiosa) of the Northern Urals.

\section{Tasks:}

1. To evaluate the above-ground and belowground phytomass of ground vegetation species of tall herb and bilberry-green moss spruce-fir forests.

2. To compare the role of microsites in providing macro- and microelements for two contrasting forest types.
3. To compare the role of ecological-coenotic groups of plants in providing macro- and microelements for two contrasting types of forests.

\section{Materials and methods}

To solve these tasks, on the basis of the previous studies of the taiga forest $[7,8,11-16]$ we selected foothill forests of the Pechora-Ilych nature reserve located in Bolsheporozhny phytogeographical area, in the lower part of the Bolshaya Porozhnyaya river basin: $62-63^{\circ} \mathrm{N} 58-59^{\circ} \mathrm{E}, 250-400 \mathrm{~m}$ above sea level. The climate of this part of the reserve is moderate continental. The average annual air temperature is $-0.4{ }^{\circ} \mathrm{C}$, the active temperatures sum above $+5{ }^{\circ} \mathrm{C}$ is $1,600-1,800{ }^{\circ} \mathrm{C}$. The vegetation period lasts for 140-150 days, and the period of active vegetation growth lasts for 90-100 days. The average sum of annual precipitation is $627 \mathrm{~mm}$, the average long-term annual precipitation is 600 to $800 \mathrm{~mm}$ in the plains [17], and 800 to $1,100 \mathrm{~mm}$ in the mountains [18].

Material for determining the phytomass and chemical composition of ground vegetation species was collected in 2017-2018 in 2 contrasting forest types of the Pechora-Ilych reserve where total mapping, determination of the area of microsites and geobotanical descriptions had been carried out previously $[11,15,16,19,20]$ :

1. In the tall herb spruce-fir forest on brown soils (Piceeto-Abieta magnoherbosa) - a unique type of forest identified and described on the territory of the Pechora-Ilych reserve (Fig. 1,A);

2. In the bilberry-green moss spruce-fir forest on podzols (Piceeto-Abieta hylocomiosa) which is the dominant type of forest in the taiga zone of Northern Eurasia (Fig. 1,B).
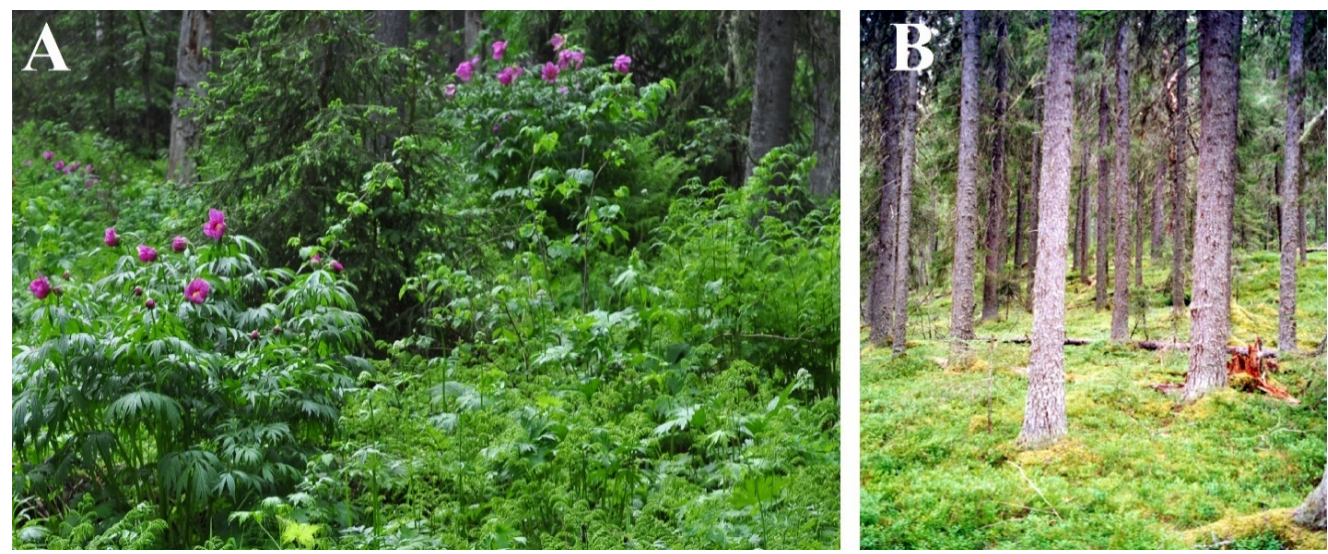

Fig. 1. Tall herb spruce-fir (A) and bilberry-green moss spruce-fir (B) forest of the Pechora-llych reserve (photo by A. A. Aleinikov)

In the studied forests typical microsites were selected, which depending on the nature of the death of a tree (break or fall) form treefall soil complex (consisting of a pit, a mound, and a fallen log) or a windbreak complex that includes a fallen log and a broken stump [8] as well as levelled regions of under-crown and inter-crown areas and near-trunk swellings. Plots $50 \times 50 \mathrm{~cm}$ in size - "monoliths" - 
were laid in three-fold replication in each microsite. Their depth corresponded to the thickness of the root layer. Living plants of all herb, dwarf shrub, and moss species were selected from each monolith to determine their species and ecologicalcoenotic groups [21]. In vascular plants, aboveground and below-ground organs were separated for drying; mosses were dried completely; the mass was determined when absolutely dry.

To measure the concentration of $\mathrm{C}$ and $\mathrm{N}$ in plant samples gas chromatography was applied using the EA 1110 (CHNS-O) element analyzer, whereas $\mathrm{Mg}, \mathrm{Al}, \mathrm{P}, \mathrm{S}, \mathrm{Cl}, \mathrm{K}, \mathrm{Ca}, \mathrm{Fe}$, and $\mathrm{Zn}$ content was determined using the SPECTROSCAN MAX-GV X-ray spectrometer and the method of measuring the mass fraction of the element in powder samples by X-ray fluorescence analysis. The findings for each defined element obtained for samples in two replications were averaged up to arithmetic mean.

Based on the ecological-coenotic classification, the following groups of vascular plants were identified: $\mathrm{Hh}$ - boreal tall herbs, br-dw - boreal dwarf shrubs; br-h - boreal small herbs, H-fern - tall ferns; md - meadow herbs, $\mathrm{Nm}$ - nemoral tall herbs, Nt-h - nitrophilic tall herbs, br-fern - boreal ferns, olg - oligotrophic herbs [21].

\section{Results and discussion}

6 types of microsites were identified in the tall herb spruce-fir forest (Piceeto-Abieta magnoherbosa): 1. under-crown areas - spaces determined by the dimensions of the tree crown projection; 2. inter-crown areas - spaces containing no adult trees and mostly occupied by herbs and dwarf shrubs; 3 . near-trunk swellings - parts of large adventitious roots at the trunk base of well-developed mature trees and hollows between them filled with decaying litter which make favourable habitats for boreal small herbs; 4 . mounds and 5. pits are elements of the tree-fall mosaic resulting from the death of large trees of good vitality with a fully developed root system. The height of a mound (a lump of soil brought to the surface by a powerful root system) in tall herb spruce-fir forests can reach one meter or more, and the depth of a pit is approximately the same.

Only 3 types of microsites were identified in the bilberry-green moss spruce-fir forest (PiceetoAbieta hylocomiosa): under-crown areas, intercrown areas and fallen logs. There are no "tree-fall mosaic" elements, i.e. mounds and pits, in this type of forest. The reasons for the lack of differences in the sets of microsites of both forest types are due to different levels of vitality of spruce and fir trees in the Piceeto-Abieta magnoherbosa and PiceetoAbieta hylocomiosa communities. In bilberrygreen moss forests, the size of trees of both species and the power of the root system is much smaller than those in tall herb spruce-fir forests; their root system is superficial. Therefore, the death of trees does not cause uprooting and bringing a large soil mound to the surface, and no clearly defined mound or pit is formed. Only a fallen $\log$, i.e. a fallen tree trunk, is clearly seen. The absence of well-defined mounds and pits in the bilberry-green moss spruce-fur forests is the evidence of the predominance of low-vitality individuals with poorly developed root systems and small tree trunks in the population [20].

The area in two types of forest (over $50 \%$ of the studied communities) is mainly occupied by under-crown and inter-crown areas. The shares of these microsites in tall herb spruce-fir forests are nearly the same, while in bilberry-green moss ones the share of under-crown areas significantly exceeds that of inter-crown areas (Table 1) indicating much lower possibilities of using photosynthetically active radiation by the ground vegetation.

Table 1

The ratio of microsite areas, species density $(\mathrm{m} \pm \mathrm{SE})$ and the ratio of phytomass of ecological-coenotic groups of plants (ECGs) in the ground vegetation of two types of spruce-fir forests

\begin{tabular}{|c|c|c|c|c|c|c|}
\hline \multirow[b]{3}{*}{ Microsites } & \multicolumn{6}{|c|}{ Forest type } \\
\hline & \multicolumn{3}{|c|}{ Tall herb spruce-fir forest } & \multicolumn{3}{|c|}{ Bilberry-green moss spruce-fir forest } \\
\hline & Area share, $\%$ & $\begin{array}{c}\text { Average } \\
\text { number } \\
\text { of vascular } \\
\text { plant species } \\
\text { per } 0.25 \mathrm{~m}^{2}\end{array}$ & $\begin{array}{c}\text { Ratio of ECGs } \\
\text { and mosses } \\
\text { by phytomass, \% }\end{array}$ & $\begin{array}{c}\text { Area share, } \\
\%\end{array}$ & $\begin{array}{c}\text { Average } \\
\text { number } \\
\text { of vascular } \\
\text { plant species } \\
\text { per } 0.25 \mathrm{~m}^{2}\end{array}$ & $\begin{array}{c}\text { Ratio of ECGs } \\
\text { and mosses } \\
\text { by phytomass, } \\
\%\end{array}$ \\
\hline 1 & 2 & 3 & 4 & 5 & 6 & 7 \\
\hline $\begin{array}{l}\text { Under- } \\
\text { crown areas }\end{array}$ & 44.4 & $13.0 \pm 3.0$ & $\begin{array}{l}\text { Hh }(76 \%), \\
\text { br-h }(9 \%), \\
\text { br-dw }(7 \%), \\
\operatorname{Nm}(6 \%), \\
\operatorname{mosses}(0.7 \%) \text {, } \\
\text { md }(1.3 \%),\end{array}$ & 54.7 & $7.2 \pm 2.9$ & $\begin{array}{l}\text { br-dw }(50 \%), \\
\text { mosses }(40 \%), \\
\text { br-h }(9 \%), \\
\text { olg }(1 \%)\end{array}$ \\
\hline
\end{tabular}


Enf of Table 1

\begin{tabular}{|c|c|c|c|c|c|c|}
\hline 1 & 2 & 3 & 4 & 5 & 6 & 7 \\
\hline $\begin{array}{l}\text { Inter-crown } \\
\text { areas }\end{array}$ & 40.8 & $13.1 \pm 4.0$ & $\begin{array}{l}\text { Hh }(87 \%), \\
\text { br-dw }(4.6 \%), \\
\text { br-h }(2 \%), \\
\text { Nm }(2 \%), \\
\text { mosses }(1.6 \%) \text {, } \\
\text { br-fern }(1.6 \%) \text {, } \\
\text { md }(0.6 \%), \\
\text { Nt-h }(0.6 \%)\end{array}$ & 34.6 & $4.7 \pm 0.9$ & $\begin{array}{l}\text { br-dw }(59 \%), \\
\text { mosses }(39 \%) \text {, } \\
\text { olg }(1,2 \%), \\
\text { br-h }(0,8 \%)\end{array}$ \\
\hline $\begin{array}{l}\text { Near-trunk } \\
\text { swellings }\end{array}$ & 8.4 & $8.3 \pm 1.5$ & $\begin{array}{l}\text { br-dw }(34 \%), \\
\text { br-h }(31 \%), \\
\text { mosses }(17 \%) \text {, } \\
\text { Hh }(12 \%), \\
\text { br-fern }(4.5 \%) \text {, } \\
\text { Nm }(1.5 \%)\end{array}$ & 0 & 0 & 0 \\
\hline Mound & 1.6 & $11.0 \pm 4.0$ & $\begin{array}{l}\text { Hh }(47 \%), \\
\text { mosses }(25 \%), \\
\text { br-dw }(11 \%), \\
\text { br-h }(8.5 \%), \\
\text { H-fern }(4 \%), \\
\text { Nm }(3 \%), \\
\text { Nt-h }(1.5 \%)\end{array}$ & 0 & 0 & 0 \\
\hline Pit & 1.6 & $10.0 \pm 3.5$ & $\begin{array}{l}\text { Hh }(41 \%), \\
\text { Nm }(18.5 \%), \\
\text { H-fern }(13 \%), \\
\text { br-dw }(9 \%), \\
\text { br-h }(9 \%), \\
\text { mosses }(8 \%), \\
\text { br-fern }(1.4 \%) \\
\text { Nt-h }(0.1 \%)\end{array}$ & 0 & 0 & 0 \\
\hline Fallen logs & 3.2 & $7.0 \pm 5.0$ & $\begin{array}{l}\text { Hh }(46 \%), \\
\text { mosses }(23 \%), \\
\text { br-dw }(14.9 \%) \text {, } \\
\text { br-h }(8 \%), \\
\text { br-fern }(5 \%), \\
\text { Nm }(3 \%), \\
\text { Nt-h }(0.1 \%)\end{array}$ & 10.7 & $4.0 \pm 1.0$ & $\begin{array}{l}\text { mosses }(62 \%), \\
\text { br-dw }(35 \%), \\
\text { br-h }(2 \%), \\
\operatorname{Nm}(0,1 \%)\end{array}$ \\
\hline
\end{tabular}

* See the legend for ecological-coenotic groups in the Materials and methods section

The total vascular plant phytomass of the ground vegetation of tall herb forests is 5 times higher than that of bilberry-green moss forests; on the contrary, phytomass of mosses of tall herb forests is 4.4 times lower than that of bilberry-green moss forests (Table 2, 3). In the tall herb spruce-fir forest, maximum phytomass of vascular plants was found in inter-crown areas where the proportion of tall herbs is high, while in the bilberry-green moss spruce-fir forest maximum phytomass was found in under-crown areas (mosses accounting for $30 \%$ of the phytomass here). Mosses in the tall herb spruce-fir forest are concentrated mainly in the inter-crown areas and on fallen logs, whereas in the bilberry-green moss spruce-fir forests - in the under-crown areas (see Table 2,3).

Table 2

Phytomass of ground vegetation in different microsites of the tall herb (Hh) spruce-fir forest

\begin{tabular}{|l|c|c|c|c|}
\hline \multirow{2}{*}{$\begin{array}{c}\text { Types } \\
\text { of microsites }\end{array}$} & \multicolumn{2}{|c|}{ Phytomass of vascular plants, $\mathrm{kg} \cdot \mathrm{ha}^{-1}$} & \multirow{2}{*}{$\begin{array}{c}\text { Phytomass } \\
\text { of mosses, } \mathrm{kg} \cdot \mathrm{ha}{ }^{-1}\end{array}$} \\
\cline { 2 - 5 } & above-ground & below-ground & total & $0.13 \pm 0.02$ \\
\hline Mound & $4.14 \pm 0.5$ & $6.16 \pm 0.3$ & $10.30 \pm 0.8$ & $58.30 \pm 9.1$ \\
\hline Fallen logs & $25.09 \pm 4.8$ & $26.88 \pm 6.9$ & $51.97 \pm 4.6$ & $9.42 \pm 1.2$ \\
\hline Under-crown area & $424.50 \pm 64.6$ & $353.76 \pm 20.4$ & $778.26 \pm 32.7$ & $80.50 \pm 4.3$ \\
\hline Inter-crown area & $1485.51 \pm 17.8$ & $2779.01 \pm 38.7$ & $4264.52 \pm 54.8$ & $0.40 \pm 0.08$ \\
\hline Near-trunk swellings & $1.82 \pm 1.3$ & $17.54 \pm 0.4$ & $19.36 \pm 0.9$ & $0.48 \pm 0.05$ \\
\hline Pit & $0.54 \pm 0.16$ & $11.27 \pm 5.5$ & $11.81 \pm 4.1$ & $\mathbf{1 4 9 . 2 3} \pm \mathbf{4 . 2}$ \\
\hline Total & $\mathbf{1 9 4 1 . 6 0} \pm \mathbf{3 6 . 7}$ & $\mathbf{3 9 4 . 6 2} \pm \mathbf{2 9 . 1}$ & $\mathbf{5 1 3 6 . 2 2} \pm \mathbf{6 6 . 5}$ & \\
\hline
\end{tabular}


Phytomass of ground vegetation in different microsites of the bilberry-green moss (Bm) spruce-fir forest

\begin{tabular}{|l|c|c|c|c|}
\hline \multirow{2}{*}{ Microsite } & \multicolumn{2}{|c|}{ Phytomass of vascular plants, $\mathrm{kg} \cdot \mathrm{ha}^{-1}$} & \multirow{2}{*}{$\begin{array}{c}\text { Phytomass of mosses, } \\
\mathrm{kg} \cdot \mathrm{ha}^{-1}\end{array}$} \\
\cline { 2 - 4 } & above-ground & below-ground & Total & $107.41 \pm 18.8$ \\
\hline Fallen logs & $67.12 \pm 4.2$ & $27.97 \pm 8.3$ & $95.09 \pm 9.2$ & $384.25 \pm 19.8$ \\
\hline Under-crown area & $617.26 \pm 39.5$ & $127.25 \pm 14.6$ & $744.51 \pm 25.4$ & $159.27 \pm 13.9$ \\
\hline Inter-crown area & $155.98 \pm 11.5$ & $29.55 \pm 8.9$ & $185.53 \pm 18.1$ & $\mathbf{6 5 0 . 9 3} \pm \mathbf{3 3 . 8}$ \\
\hline Total & $\mathbf{8 4 0 . 3 6} \pm \mathbf{4 8 . 6}$ & $\mathbf{1 8 4 . 7 7} \pm \mathbf{2 1 . 3}$ & $\mathbf{1 0 2 5 . 1 3} \pm \mathbf{4 5 . 6}$ & \\
\hline
\end{tabular}

The below-ground phytomass in the tall herb spruce-fir forest was significantly higher than the above-ground one (with the difference of over $1,200 \mathrm{~kg} \cdot \mathrm{ha}^{-1}$ ), whereas, on the contrary, the aboveground phytomass in the bilberry-green moss sprucefir forest significantly exceeded the below-ground one (the difference is $650 \mathrm{~kg} \cdot \mathrm{ha}^{-1}$ ) (see Table 2, 3;
Fig. 2), which is likely due to fundamental differences in soil conditions: tall herb forests are located on the richest soils (forest brown soils), while parts of bilberry-green moss forests - on much poorer soils (podzols) [22] and in tall herb forests, species with large underground organs (peony, aconite) make a big contribution to the phytomass.

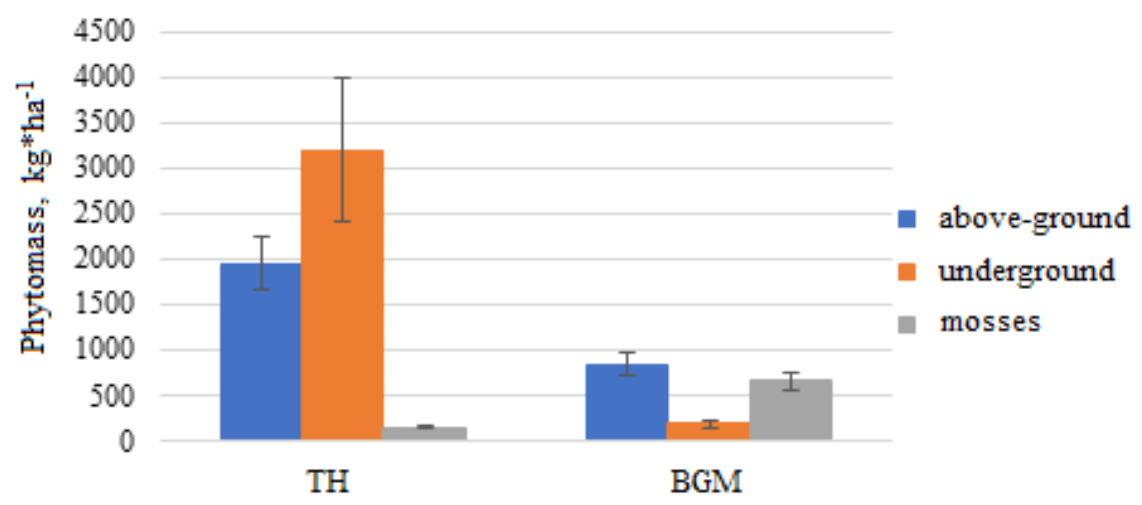

Type of forest

Fig. 2. The above-ground, and the below-ground phytomass of vascular plants and total phytomass of mosses in tall herb $(\mathrm{Hh})$ and bilberry-green moss $(\mathrm{Bm})$ spruce-fir forests of the Pechora-llych reserve

Significant differences in the phytomass of ground vegetation in different types of forest and the significance of the contribution of microsites and ecological-coenotic groups of plants to the total phytomass of the ground vegetation were also demonstrated in previous studies of dark coniferous forests of the Pechora-Ilych reserve $[11,15,16]$. The crucial role of under-crown and inter-crown areas in providing the total phytomass of vascular plants of the ground vegetation $(96 \%)$ was demonstrated on the example of tall herb spruce-fir forests, which is due to the small area of other microsites, i. e. fallen logs, pits, mounds and near-trunk swellings. A low proportion of mosses in the total phytomass of the ground vegetation of tall herb forests was also revealed [16]. Our measurements have shown that the concentration of vascular plant phytomass in the under-crown and inter-crown areas reaches $98 \%$ in the tall herb spruce-fir forest (see Table 2), and $90 \%$ in the bilberry-green moss spruce-fir forest. However, the role of other microsites, especially fallen logs, is significant for the moss cover phytomass: in the tall herb sprucefir forest, fallen $\operatorname{logs}$ account for $40 \%$ of the total moss phytomass of the entire forest type, and in the bilberry-green moss forest - for $16 \%$. This highlights the essential coenotic role of all elements of the mound-and-pit topography in the formation of the ground vegetation phytomass [11].

The study of the content of chemical elements with the consideration of the area of microsites shows that the greatest contribution to the accumulation of macro- and microelements is made by under-crown and inter-crown areas (Fig. 3). The role of under-crown and inter-crown areas in the accumulation of $\mathrm{C}, \mathrm{N}, \mathrm{K}, \mathrm{Ca}, \mathrm{Al}, \mathrm{S}$, and $\mathrm{P}$ is approximately the same in two types of forest, but taking into account the reserves of phytomass, the content of these chemical elements in tall herb spruce-fir forests is 3-10 times higher than in bilberry-green moss forests. In both forest types, under-crown areas contribute more to the accumulation of $\mathrm{Al}, \mathrm{Fe}$, $\mathrm{Mg}, \mathrm{Mn}$, and $\mathrm{Cr}$; whereas inter-crown areas - to the accumulation of $\mathrm{Cl}, \mathrm{Sr}$, and $\mathrm{Rb}$. Having said that, despite the significant high differences in the phytomass of tall herb and bilberry-green moss spruce-fir forests, the contents of Sr turned out to be 10 times higher, and of $\mathrm{Rb}-18$ times higher in the bilberry-green moss forest as compared to the 
tall herb forest. The greatest contribution to the content of $\mathrm{Rb}$ is made by Avenella flexuosa, of $\mathrm{Sr}-$ by Avenella flexuosa, Orthilia secunda, Dicranum majus, and Polytrichum commune, which grow in the bilberry-green moss forest mostly in intercrown areas and enjoy higher phytomass in the bilberry-green moss spruce-fir forest than in the tall herb spruce-fir forest. Fallen logs, pits, and mounds also contribute to the accumulation of $\mathrm{C}$, $\mathrm{N}, \mathrm{K}, \mathrm{Ca}, \mathrm{Al}, \mathrm{S}, \mathrm{P}, \mathrm{Fe}, \mathrm{Ni}$, and $\mathrm{Zn}$ in two types of forest; however, the contribution of these microsites is about 6 times less than that of under-crown and inter-crown areas due to their smaller area.

The study of ecological-coenotic groups of plants regarding the content of chemical elements with the consideration of phytomass shows that the greatest contribution to the accumulation of macroand microelements in the tall herb spruce-fir forest is made by the plants of nitrophilic tall herbs, nemoral tall herbs, boreal dwarf shrubs and boreal small herbs groups (Fig. 4). The groups of tall herb species contributed most to the content of $\mathrm{C}, \mathrm{N}, \mathrm{K}$, $\mathrm{Ca}, \mathrm{Al}, \mathrm{S}, \mathrm{P}, \mathrm{Cl}, \mathrm{Zn}, \mathrm{Ni}, \mathrm{Fe}, \mathrm{Mn}$ and $\mathrm{Cr}$, i.e. all the studied macro- and microelements except $\mathrm{Sr}$ and $\mathrm{Ru}$.

The group of boreal dwarf shrubs in comparison with other ECGs differs significantly due to the high content of $\mathrm{Mg}, \mathrm{Fe}, \mathrm{Mn}$, and $\mathrm{Cr}$. In the bilberry-green moss spruce-fir forest, the largest contribution to the content of the studied macro- and microelements is made by plants of the oligotrophic group of species and boreal small herbs (see Fig. 4).

The comparison of the elements content in the above-ground and below-ground phytomass of vascular plants shows that in both forest types the above-ground parts of plants contain much more $\mathrm{C}$, $\mathrm{N}, \mathrm{Ca}, \mathrm{K}, \mathrm{Mg}, \mathrm{P}, \mathrm{Ni}$, and $\mathrm{Mn}$, whereas the belowground parts enjoy higher $\mathrm{Fe}$ content. The content of Al does not differ in the above- and below-ground parts of plants in the two types of forest. The content of $\mathrm{Cr}, \mathrm{Cl}$ and $\mathrm{S}$ in the tall herb spruce-fir forest is higher in below-ground than in above-ground phytomass, while in the bilberry-green moss forest, on the contrary, the content of these elements is higher in the above-ground parts of plants than in the below-ground ones. Zn content does not differ significantly between the above-ground and the below-ground plant parts in the tall herb sprucefir forest, whereas in bilberry-green moss forest $\mathrm{Zn}$ content is significantly higher in the aboveground part in comparison with the below-ground part (Fig. 5).

Studies of forest ecosystem productivity estimate carbon and nitrogen stock as the most important elements of the global cycle in the first place [23-26]. According to the literature data, in the green moss spruce forests of the middle taiga (the Komi Republic), the carbon content in the above-ground part of the ground vegetation is about $800 \mathrm{~kg} \cdot \mathrm{ha}^{-1}$, with mosses accounting for $70 \%$ of the carbon content [27]. In our research, the carbon content in the above-ground part of the bilberry-green moss spruce-fir forest plants is about $450 \mathrm{~kg} \cdot \mathrm{ha}^{-1}$, while mosses account for no more than $25 \%$ of the carbon content, and boreal dwarf shrubs and boreal small herbs account for more than $70 \%$. In the tall herb spruce-fir forest, the carbon content in the above-ground part is $1,500 \mathrm{~kg} \cdot \mathrm{ha}^{-1}$, mosses account for $15 \%$, and plants of the tall herb group - for over $60 \%$.

It is known that the productivity of modern boreal forests is largely limited by the nitrogen content [28]. Our research shows that the nitrogen stock in the ground vegetation of the tall herb spruce-fir forest are more than 4 times higher $\left(80 \mathrm{~kg} \cdot \mathrm{ha}^{-1}\right)$ than in the bilberry-green moss sprucefir forest $\left(18 \mathrm{~kg} \cdot \mathrm{ha}^{-1}\right)$ (see Fig. 3-5). In tall herb forests, the main contribution to nitrogen accumulation is made by species of nitrophilic tall herbs, nemoral tall herbs, boreal dwarf shrubs and boreal small herbs groups; in bilberry-green moss forests by boreal small herbs group.

In dark coniferous forests, the role of ground vegetation in bringing nitrogen and mineral elements back into the soil is significantly higher than in mixed and deciduous forests, since coniferous species return only a small part (as compared to deciduous plants) of nutrients involved in the biological cycle to soil with annual litter, and ground vegetation litter is the major source of mineral nutrients for the soil [29]. Therefore, the contribution of plants of the tall herb group, which dominate in terms of phytomass, determines the unique productivity of this type of taiga forests in comparison with typical bilberrygreen moss forests. Significantly high reserves of macro- and most of the microelements in the ground vegetation of tall herb spruce-fir forests in comparison with bilberry-green moss forests cause the differences in soil fertility and the content of mineral nutrition elements in the soil of these forests [22], soil invertebrates [30,31], and in microbial biomass [32]. High content of carbon, calcium and magnesium in the phytomass of the ground vegetation, particularly, of the group of tall herbs causes significant differences in the biomass of soil saprophages, especially earthworms [31], the active functioning of which requires a sufficient content of carbon and divalent cations of calcium and magnesium in the soil, which reduce the acidity of the soil solution. 


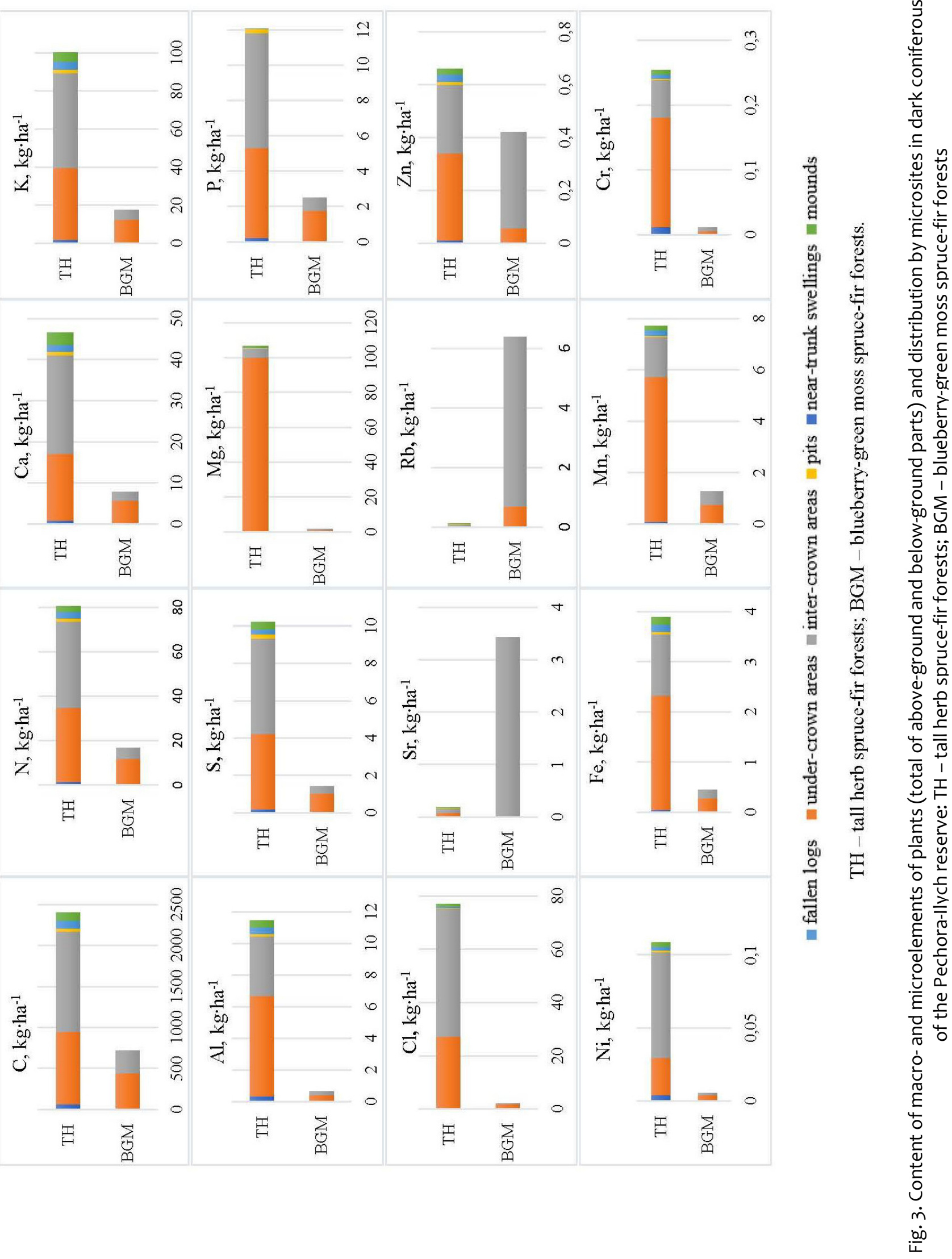


$\frac{1}{\dot{s}}$

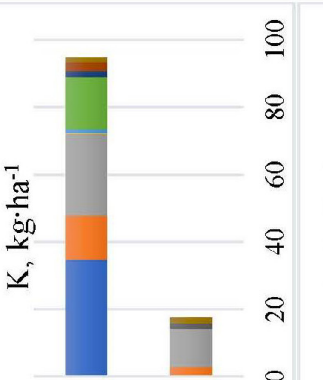

$\Xi \quad \sum_{0}$
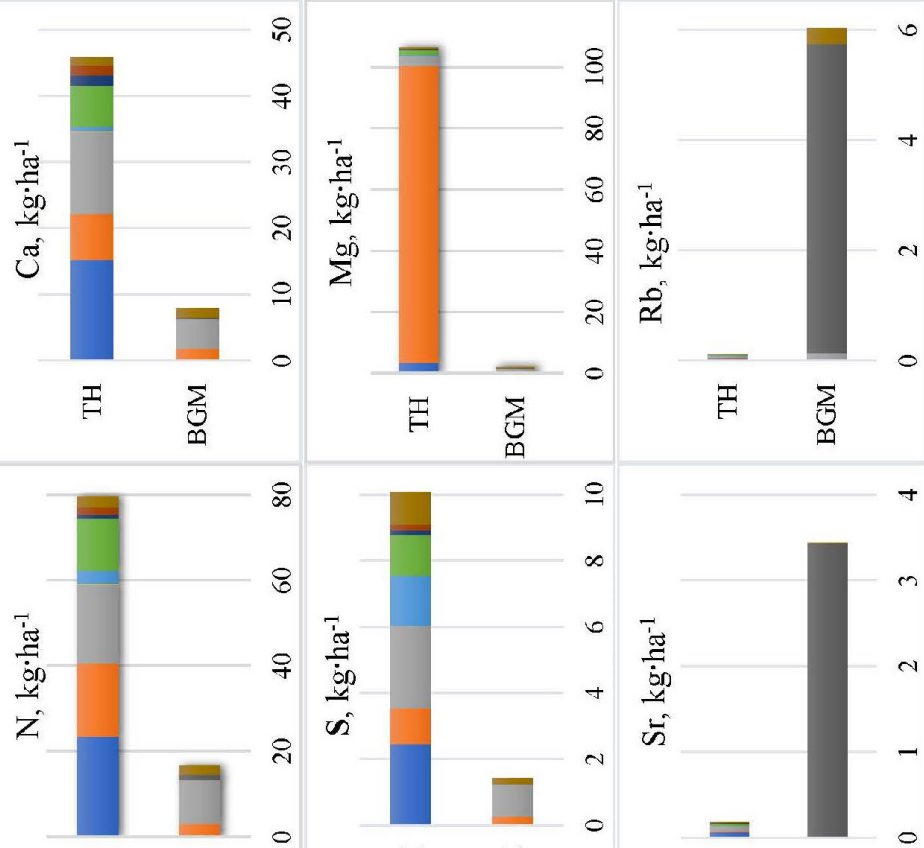

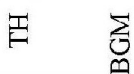

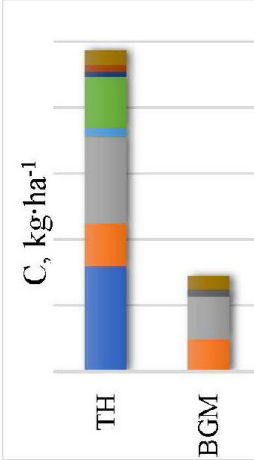

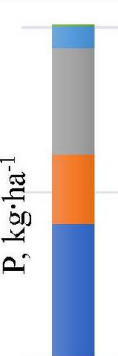
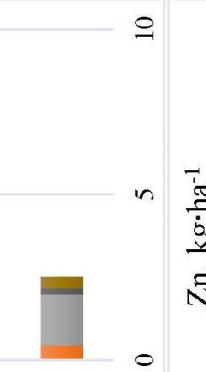

F

电

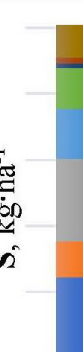

I 츰

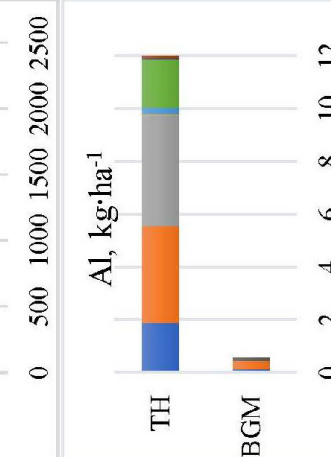

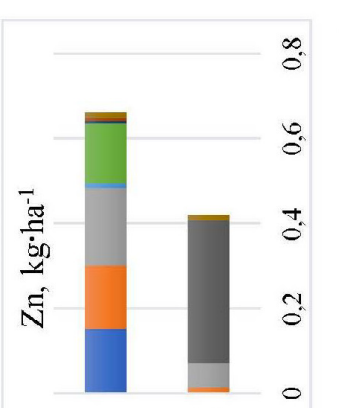

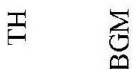

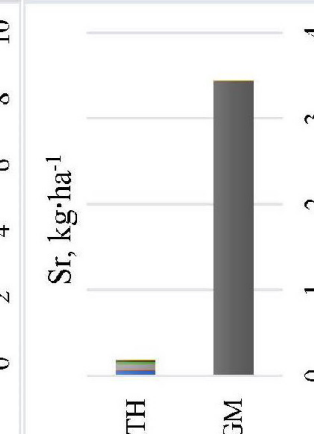

E 厗

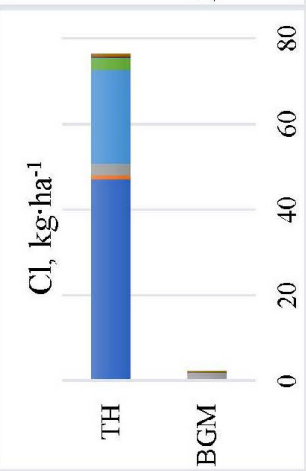

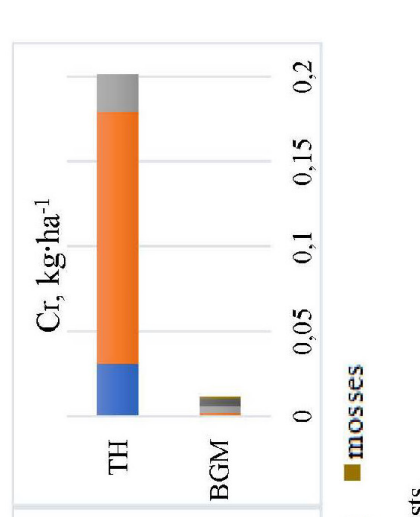
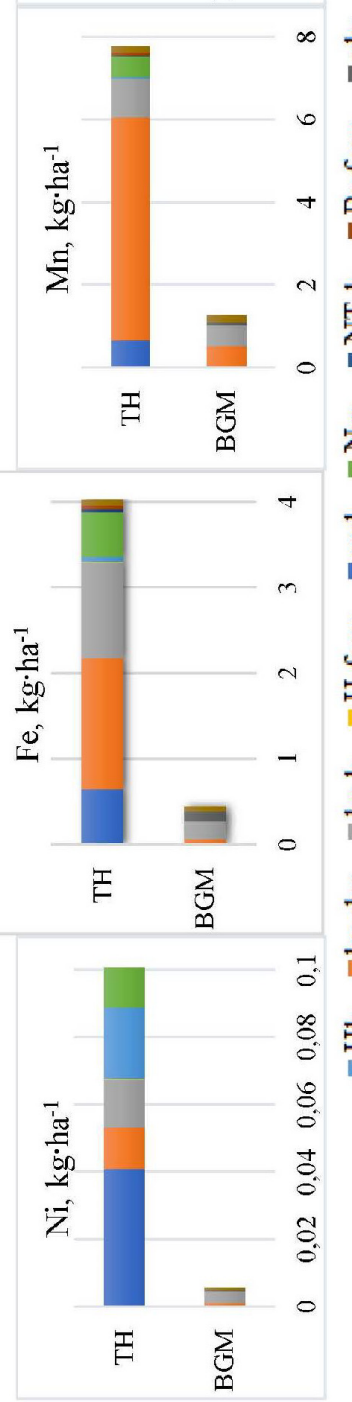

气̆

난

บั

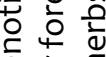

प्र

당

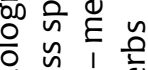

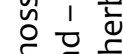

E E U.

ลे ญे

क力口

竞竞

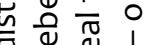

응 잉

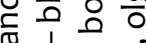

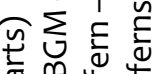

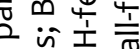

苟出

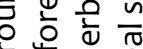

क人⿻一𠃋十

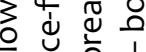

ป ำ

के 1 क्ष

元证高

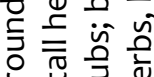

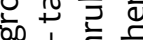

$\dot{d} \pm \frac{n}{n} \frac{1}{\frac{1}{\pi}}$

ठ듀

ते

त

인 3

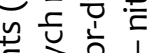

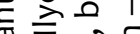

즘 产 定

पे क्षे

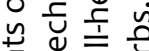

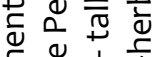

है 1

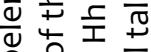

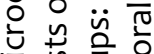

है जै

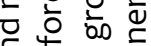

กิ

ㅇํㄴ 윤

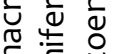

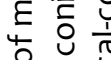

tri

苞竞管

苍造

西去

$\dot{\tau} . \cong$

$\dot{D i 0}$ 

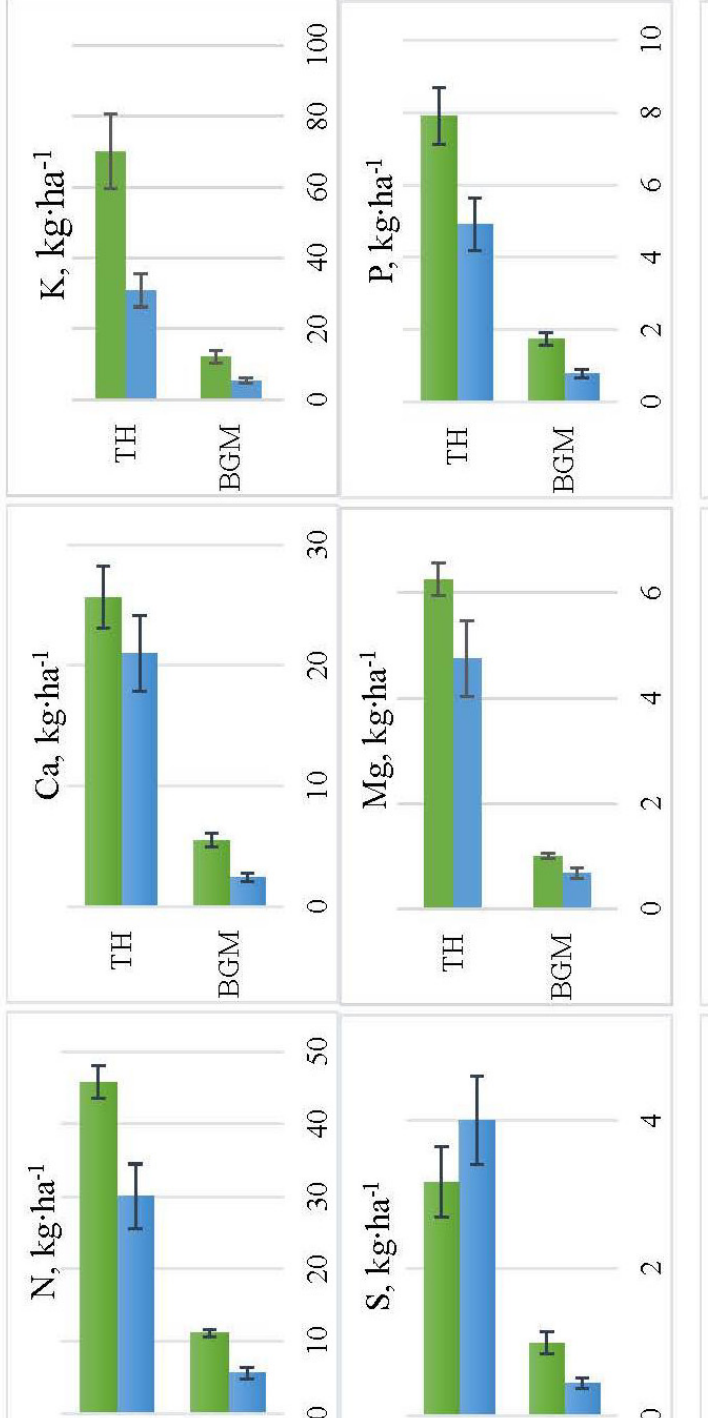

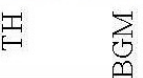

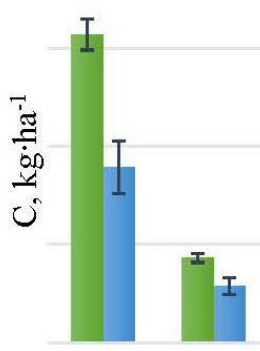

声忘
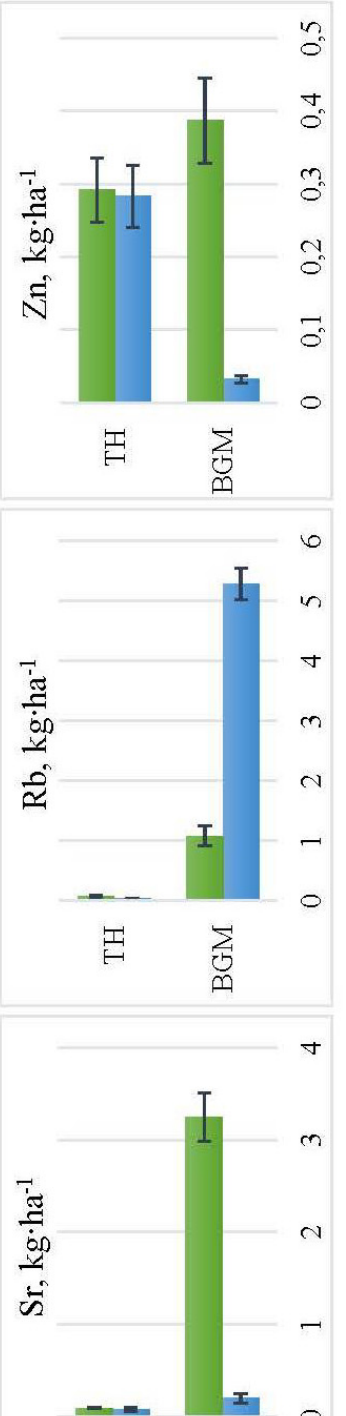

画 $\sum_{0}$

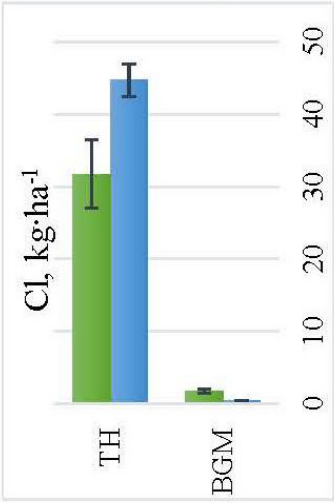

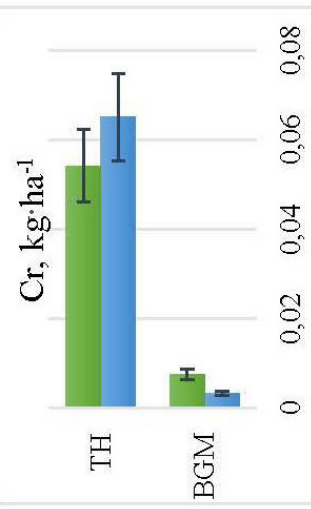
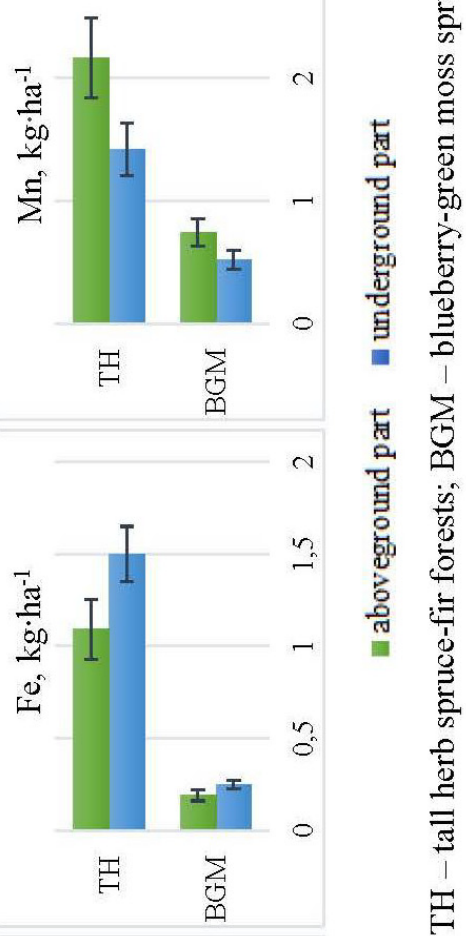

$\sum \sum$

으

बे

든

กิ

5 辛

ํํㅇ d

$\stackrel{1}{\partial}$ ำ

然

$\stackrel{\frac{1}{2}}{\leftrightarrows}$

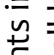

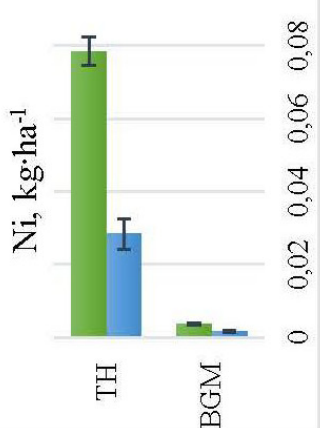




\section{Conclusion}

In the tall herb spruce-fir forest - a unique type of dark coniferous forests - the maximum phytomass of vascular plants is found in inter-crown areas where the proportion of tall herbs is high ( $89 \%$ ), while in the dominant type of dark coniferous forests - bilberry-green moss forest, the maximum phytomass of ground vegetation is concentrated in under-crown areas where mosses account for $50 \%$ of the phytomass and boreal dwarf shrubs - for $40 \%$. The total phytomass of vascular plants in the ground vegetation of tall herb forests is 5 times higher than that of bilberry-green-moss forests. The phytomass of mosses of tall herb forests is 4.4 times lower in comparison with bilberry-green moss forests. Mosses of the tall herb spruce-fir forest are concentrated mainly in inter-crown areas and on fallen logs, whereas in the bilberry-green moss spruce-fir forest - in the under-crown areas.

The study of ecological-coenotic groups of plants regarding the content of chemical elements with the consideration of phytomass shows that the greatest contribution to the accumulation of macro- and microelements in the tall herb spruce-fir forest is made by the plants of nitrophilic tall herbs, nemoral tall herbs, boreal dwarf shrubs and boreal small herbs groups, and by mosses and boreal dwarf shrubs in the bilberry-green moss spruce-fir forest. The comparison of the elements content of the above-ground and below-ground phytomass of vascular plants shows that in both forest types, the content of $\mathrm{C}, \mathrm{N}, \mathrm{Ca}, \mathrm{K}, \mathrm{Mg}, \mathrm{P}, \mathrm{Ni}$, and $\mathrm{Mn}$ was significantly higher in the above-ground parts of plants, but $\mathrm{Fe}$ content was higher in belowground parts.

The suggested differentiated approach to the assessment of the content of biogenic elements in the ground vegetation including the contribution of the above-ground and the below-ground plants phytomass, the composition of the ecological-coenotic groups and microsite arrangement of forests makes it possible to assess the current productivity of forest communities. The data obtained previously and new results are necessary for evaluating the productivity of forest ecosystems with an analysis of the role of the most well-preserved forest types including tall herb spruce-fir forests.

\section{Библиографический список}

1. Esseen, P. A. Boreal forests / P. A. Esseen, B. Ehnström, L. Ericson, K. Sjöberg // Ecological bulletins. - 1997. № 46. - P. 16-47.

2. Биотическая регуляция окружающей среды / В. В. Горшков, В. Г. Горшков, В. И. Данилов-Данльян, К. С. Лосев, А. М. Макарьева // Экология. - 1999. - № 2. - С. 105-113.

3. Леви, К. Г. Радиоуглеродная хронология природных и социальных феноменов Северного полушария / К. Г. Леви, Н. В. Задонина, С. А. Язев. - Иркутск : Изд-во Иркутского гос. ун-та, 2009. - Т. 1. - 715 с.

4. Леви, К. Г. Радиоуглеродная хронология природных и социальных феноменов Северного полушария / К. Г. Леви, Н. В. Задонина, С. А. Язев. - Иркутск : Изд-во Иркутского гос. ун-та, 2011. - Т. 2. - 527 с.

5. Леви, К. Г. Радиоуглеродная хронология природных и социальных феноменов Северного полушария / К. Г. Леви, Н. В. Задонина, С. А. Язев. - Иркутск : Изд-во Иркутского гос. ун-та, 2011. - Т. 3. - 847 с.

6. Smirnova, O. V. Natural zonality of the forest belt of Northern eurasia: myth or reality? Part 1 (literature review) / O. V. Smirnova, A. P. Geraskina, V. N. Korotkov // Russian Journal of Ecosystem Ecology. - 2020. - Vol. 5 (1). DOI 10.21685/2500-0578-2020-1-2.

7. Восточноевропейские леса: история в голоцене и современность / отв. ред. О. В. Смирнова. - Москва : Наука, 2004. - Кн. 1. - 479 с.

8. European Russian Forest. Their Current State and Features of Their History / ed. by O. V. Smirnova, M. V. Bobrovsky, L. G. Khanina. - Heidelberg : Springer, 2017. - 566 p.

9. Smirnova, O. V. The concept "complementarity" as the basis for model and nature reconstruction of potential biota in the current climate / O. V. Smirnova, A. P. Geraskina, A. A. Aleynikov // Russian Journal of Ecosystem Ecology. - 2018. - Vol. 3 (3). - DOI 10.21685/2500-0578-2018-3-1.

10. Высокотравные таежные леса восточной части Европейской России / Л. Б. Заугольнова, О. В. Смирнова, Т. Ю. Браславская, С. В. Дегтева, Т. С. Проказина, Д. Л. Луговая // Растительность России. - 2009. № 15.- C. 3-26.

11. Micromosaic structure and phytomass of ground vegetation in main types of dark conifer forests in the PechoraIlych state nature reserve / D. L. Lugovaya, O. V. Smirnova, M. V. Zaprudina, A. A. Aleynikov, V. E. Smirnov // Russian Journal of Ecology. - 2013. - Vol. 44 (1). - P. 3-10.

12. Smirnova, O. V. Model reconstruction of restored taiga forest cover / O. V. Smirnova, D. V. Lugovaya, T. S. Prokazina // Biology Bulletin. - 2013. - Vol. 3 (6). - P. 493-504.

13. Smirnova, O. V. Refugium of the Boreal Forests of the Circumpolar Urals / O. V. Smirnova, N. E. Shevchenko, L. G. Khanina, M. V. Bobrovsky // Biology Bulletin. - 2018. - Vol. 45 (2) - P. 212-218. 
14. Shevchenko, N. E. Refugia for the floristic diversity of northern Ural dark conifer forests as markers of natural vegetation of the Eastern European taiga / N. E. Shevchenko, O. V. Smirnova // Russian Journal of Ecology. 2017. - Vol. 48 (3). - P. 212-218.

15. Пространственная неоднородность почвенно-растительного покрова темнохвойных лесов в ПечороИлычском заповеднике / О. В. Смирнова, А. А. Алейников, А. А. Семиколенных, А. Д. Бовкунов, М. В. Запрудина, Н. С. Смирнов // Лесоведение. - 2011. - № 6. - С. 67-78.

16. Запрудина, М. В. Микромозаичная организация травяно-кустарничкового и мохового покрова высокотравных пихто-ельников с кедром нижней части бассейна реки Большая Порожняя (приток р. Печора) / М. В. Запрудина, В. Э. Смирнов // Труды Печоро-Илычского заповедника. - 2010. - № 16. - С. 60-68.

17. Атлас Республики Коми по климату и гидрологии / под ред. А. И. Таскаева. - Москва : ДиК, Дрофа, 1997. $116 \mathrm{c}$.

18. Бобрецов, А. В. Природные условия Печоро-Илычского заповедника / А. В. Бобрецов, В. В. Теплов // Закономерности полувековой динамики биоты девственной тайги Северного Предуралья. - Сыктывкар, 2000. - C. 6-21.

19. Efimenko, A. S. The role of microsites in the natural regeneration of trees in boreal tall-herb dark coniferous forests of the Northern Urals / A. S. Efimenko, A. A. Aleinikov // Biology Bulletin. - 2019. - № 2. - C. $200-209$.

20. Aleinikov, A. A. Tall-Herb Boreal Forests on North Ural / A. A. Aleinikov, N. S. Smirnov, O. V. Smirnova // Russian Journal of Ecosystem Ecology. - 2016. - Vol. 1 (3). - DOI 10.21685/2500- 0578-2016-3-3.

21. Ценофонд лесов Европейской России / под ред. Л. Б. Заугольной, О. В. Морозовой. - 2006. - URL: http://cepl.rssi.ru/bio/flora/main.htm (дата обращения: 15.04.2020).

22. Semikolennykh, A. A. Soils and the soil cover of the taiga zone in the northern Urals (upper reaches of the Pechora River) / A. A. Semikolennykh, A. D. Bovkunov, A. A. Aleinikov // Eurasian soil science. - 2013. - Vol. 46 (8). P. 821-832.

23. Peng, C. Effects of harvesting regimes on carbon and nitrogen dynamics of boreal forests in central Canada: a process model simulation / C. Peng, H. Jiang, M. J. Apps, Y. Zhang // Ecological Modelling. - 2002. - Vol. 155 (2-3). P. 177-189.

24. Yang, Y. Carbon and nitrogen dynamics during forest stand development: a global synthesis / Y. Yang, Y. Luo, A. C. Finzi // New Phytologist. - 2011. - Vol. 190 (4). - P. 977-989.

25. Smith, R. J. Sensitivity of carbon stores in boreal forest moss mats-effects of vegetation, topography and climate / R. J. Smith, S. Jovan, A. N. Gray, B. McCune // Plant and soil. - 2017. - Vol. 421 (1-2). - P. 31-42.

26. Zamolodchikov, D. G. Dynamic pattern of carbon balance in the forests of federal districts of the Russian Federation / D. G. Zamolodchikov, V. I. Grabowsky, O. V. Chestnykh // Forest science issues. - 2019. - Vol. 2 (2). P. 1-19.

27. Тужилкина, В. В. Структура фитомассы и запасы углерода в растениях напочвенного покрова еловых лесов на северо-востоке европейской России / В. В. Тужилкина // Растительные ресурсы. - 2012. - Т. 48. №. 1. - C. 44-50.

28. Mahendrappa, M. K. Nutrient dynamics and growth response in a fertilized black spruce stand / M. K. Mahendrappa, P. O. Salonius // Soil Science Society of America Journal. - 1982. - Vol. 46 (1). - P. 127-133.

29. Перевозникова, В. Д. Структура запасов наземной фитомассы в свежих шелкопрядниках пихтовой тайги Нижнего Приангарья / В. Д. Перевозникова, Ю. Н. Баранчиков // Энтомологические исследования в Сибири. - Красноярск : КФ СО РЭО, 2002. - Вып. 2. - С. 166-180.

30. Гончаров, А. А. Роль микромозаичной организации лесных экосистем в формировании структуры почвенной мезофауны на примере пихто-ельника высокотравного в верховьях реки Печора / А. А. Гончаров, Е. Ю. Храмова, А. А. Алейников // Труды Печоро-Илычского заповедника. - Сыктывкар : Изд-во Коми НЦ УрО РАН, 2015. - Вып. 17. - С. 63-68

31. Geraskina, A. P. The population of earthworms (Lumbricidae) in the main types of dark coniferous forests in Pechora-Ilych Nature Reserve / A. P. Geraskina // Biology Bulletin. - 2016. - Vol. 43 (8). - P. 819-830.

32. Квиткина, А. К. Микробная биомасса почв связана с типом сообщества и видовым составом травянистого покрова лесов / А. К. Квиткина, Н. С. Смирнов // Проблемы антропогенной трансформация природной среды : материалы Междунар. конф. - Пермь, 2019. - С. 255-258.

\section{References}

1. Esseen P. A., Ehnström B., Ericson L., Sjöberg K. Ecological bulletins. 1997, no. 46, pp. 16-47.

2. Gorshkov V. V., Gorshkov V. G., Danilov-Danl'yan V. I., Losev K. S., Makar'eva A. M. Ekologiya [Ecology]. 1999, no. 2, pp. 105-113. [In Russian]

3. Levi K. G., Zadonina N. V., Yazev S. A. Radiouglerodnaya khronologiya prirodnykh i sotsial'nykh fenomenov Severnogo polushariya [Radiocarbon chronology of natural and social phenomena of the Northern hemisphere]. Irkutsk: Izd-vo Irkutskogo gos. un-ta, 2009, vol. 1, 715 p. [In Russian]

4. Levi K. G., Zadonina N.V., Yazev S. A. Radiouglerodnaya khronologiya prirodnykh i sotsial'nykh fenomenov Severnogo polushariya [Radiocarbon chronology of natural and social phenomena of the Northern hemisphere]. Irkutsk: Izd-vo Irkutskogo gos. un-ta, 2011, vol. 2, 527 p. [In Russian] 
5. Levi K. G., Zadonina N. V., Yazev S. A. Radiouglerodnaya khronologiya prirodnykh i sotsial'nykh fenomenov Severnogo polushariya [Radiocarbon chronology of natural and social phenomena of the Northern hemisphere]. Irkutsk: Izd-vo Irkutskogo gos. un-ta, 2011, vol. 3, 847 p. [In Russian]

6. Smirnova O. V., Geraskina A. P., Korotkov V. N. Russian Journal of Ecosystem Ecology. 2020, vol. 5 (1). DOI 10.21685/2500-0578-2020-1-2. [In Russian]

7. Vostochnoevropeyskie lesa: istoriya v golotsene $i$ sovremennost' [East European forests: history in the Holocene and modern times]. Execut. ed. O. V. Smirnova. Moscow: Nauka, 2004, bk. 1, 479 p. [In Russian]

8. European Russian Forest. Their Current State and Features of Their History. Ed. by O. V. Smirnova, M. V. Bobrovsky, L. G. Khanina. Heidelberg: Springer, 2017, 566 p.

9. Smirnova O. V., Geraskina A. P., Aleynikov A. A. Russian Journal of Ecosystem Ecology. 2018, vol. 3 (3). DOI 10.21685/2500-0578-2018-3-1. [In Russian]

10. Zaugol'nova L. B., Smirnova O. V., Braslavskaya T. Yu., Degteva S. V., Prokazina T. S., Lugovaya D. L. Rastitel'nost' Rossii [Vegetation of Russia]. 2009, no. 15, pp. 3-26. [In Russian]

11. Lugovaya D. L., Smirnova O. V., Zaprudina M. V., Aleynikov A. A., Smirnov V. E. Russian Journal of Ecology. 2013, vol. 44 (1), pp. 3-10. [In Russian]

12. Smirnova O. V., Lugovaya D. V., Prokazina T. S. Biology Bulletin. 2013, vol. 3 (6), pp. $493-504$.

13. Smirnova O. V., Shevchenko N. E., Khanina L. G., Bobrovsky M. V. Biology Bulletin. 2018, vol. 45 (2), pp. $212-218$.

14. Shevchenko N. E., Smirnova O. V. Russian Journal of Ecology. 2017, vol. 48 (3), pp. 212-218. [In Russian]

15. Smirnova O. V., Aleynikov A. A., Semikolennykh A. A., Bovkunov A. D., Zaprudina M. V., Smirnov N. S. Lesovedenie [Forest studies]. 2011, no. 6, pp. 67-78. [In Russian]

16. Zaprudina M. V., Smirnov V. E. Trudy Pechoro-Ilychskogo zapovednika [Proceedings of the Pechora-Ilych Nature Reserve]. 2010, no. 16, pp. 60-68. [In Russian]

17. Atlas Respubliki Komi po klimatu i gidrologii [Atlas of the Komi Republic: on the climate and hydrology]. Ed. by A. I. Taskaev. Moscow: DiK, Drofa, 1997, 116 p. [In Russian]

18. Bobretsov A. V., Teplov V. V. Zakonomernosti poluvekovoy dinamiki bioty devstvennoy taygi Severnogo Predural'ya [Regularities of 50-year dynamics of the Northern Cis-Ural region primeval taiga biota]. Syktyvkar, 2000, pp. 6-21. [In Russian]

19. Efimenko A. S., Aleinikov A. A. Biology Bulletin. 2019, no. 2, pp. 200-209.

20. Aleinikov A. A., Smirnov N. S., Smirnova O. V. Russian Journal of Ecosystem Ecology. 2016, vol. 1 (3). DOI 10.21685/2500- 0578-2016-3-3. [In Russian]

21. Tsenofond lesov Evropeyskoy Rossii [European Russia forest price fund]. Eds. L. B. Zaugol'naya, O. V. Morozova. 2006. Available at: http:/cepl.rssi.ru/bio/flora/main.htm (accessed Apr. 15, 2020). [In Russian]

22. Semikolennykh A. A., Bovkunov A. D., Aleinikov A. A. Eurasian soil science. 2013, vol. 46 (8), pp. $821-832$.

23. Peng C., Jiang H., Apps M. J., Zhang Y. Ecological Modelling. 2002, vol. 155 (2-3), pp. 177-189.

24. Yang Y., Luo Y., Finzi A. C. New Phytologist. 2011, vol. 190 (4), pp. 977-989.

25. Smith R. J., Jovan S., Gray A. N., McCune B. Plant and soil. 2017, vol. 421 (1-2), pp. 31-42.

26. Zamolodchikov D. G., Grabowsky V. I., Chestnykh O. V. Forest science issues. 2019, vol. 2 (2), pp. 1-19.

27. Tuzhilkina V. V. Rastitel'nye resursy [Plant resources]. 2012, vol. 48, no. 1, pp. 44-50. [In Russian]

28. Mahendrappa M. K., Salonius P. O. Soil Science Society of America Journal. 1982, vol. 46 (1), pp. $127-133$.

29. Perevoznikova V. D., Baranchikov Yu. N. Entomologicheskie issledovaniya v Sibiri [Entomological research in Siberia]. Krasnoyarsk: KF SO REO, 2002, iss. 2, pp. 166-180. [In Russian]

30. Goncharov A. A., Khramova E. Yu., Aleynikov A. A. Trudy Pechoro-Ilychskogo zapovednika [Proceedings of the Pechora-Ilych Nature Reserve]. Syktyvkar: Izd-vo Komi NTs UrO RAN, 2015, iss. 17, pp. 63-68. [In Russian]

31. Geraskina A. P. Biology Bulletin. 2016, vol. 43 (8), pp. 819-830.

32. Kvitkina A. K., Smirnov N. S. Problemy antropogennoy transformatsiya prirodnoy sredy: materialy Mezhdunar. konf. [Problems of anthropogenic transformation of natural environment: proceedings of International conference]. Perm, 2019, pp. 255-258. [In Russian] 